\title{
Social exclusion in the context of globalization
}

Working Paper No. 18

\section{Jan Breman}

Policy Integration Department

World Commission on the Social dimension on Globalization

International Labour Office

Geneva

May 2004

Working papers are preliminary documents circulated

to stimulate discussion and obtain comments 
Copyright $\mathbb{C}$ International Labour Organization 2004

Publications of the International Labour Office enjoy copyright under Protocol 2 of the Universal Copyright Convention. Nevertheless, short excerpts from them may be reproduced without authorization, on condition that the source is indicated. For rights of reproduction or translation, application should be made to the Publications Bureau (Rights and Permissions), International Labour Office, CH-1211 Geneva 22, Switzerland. The International Labour Office welcomes such applications.

Libraries, institutions and other users registered in the United Kingdom with the Copyright Licensing Agency, 90 Tottenham Court Road, London W1T 4LP [Fax: (+44) (0)20 7631 5500; email: cla@cla.co.uk], in the United States with the Copyright Clearance Center, 222 Rosewood Drive, Danvers, MA 01923 [Fax: (+1) (978) 750 4470; email: info@copyright.com] or in other countries with associated Reproduction Rights Organizations, may make photocopies in accordance with the licences issued to them for this purpose.

ISBN 92-2-115790-3 (printed version)

ISBN 92-2-115791-1 (web version)

First published 2004

The designations employed in ILO publications, which are in conformity with United Nations practice, and the presentation of material therein do not imply the expression of any opinion whatsoever on the part of the International Labour Office concerning the legal status of any country, area or territory or of its authorities, or concerning the delimitation of its frontiers.

The responsibility for opinions expressed in signed articles, studies and other contributions rests solely with their authors, and publication does not constitute an endorsement by the International Labour Office of the opinions expressed in them.

Reference to names of firms and commercial products and processes does not imply their endorsement by the International Labour Office, and any failure to mention a particular firm, commercial product or process is not a sign of disapproval.

ILO publications can be obtained through major booksellers or ILO local offices in many countries, or direct from ILO Publications, International Labour Office, $\mathrm{CH}-1211$ Geneva 22, Switzerland. Catalogues or lists of new publications are available free of charge from the above address, or by email: pubvente@ilo.org

Visit our website: www.ilo.org/publns 


\section{Social exclusion in the context of globalization}

\section{Contents}

Foreword iii

Preface V

1. The notion of exclusion .................................................................................................... 1

2. Globalization and the promise of inclusion ..................................................................... 2

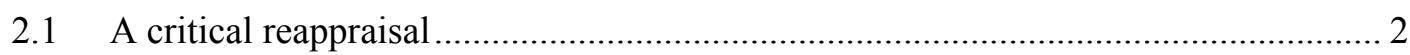

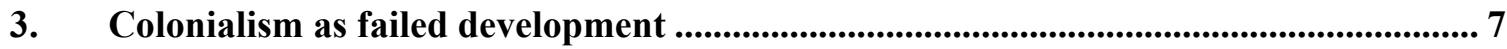

4. Changes to landless existence in the transition to a capitalist regime ..............................8

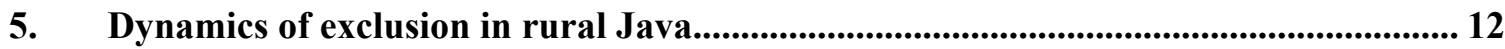

6. The process of informalization in Ahmedabad ....................................................................... 17

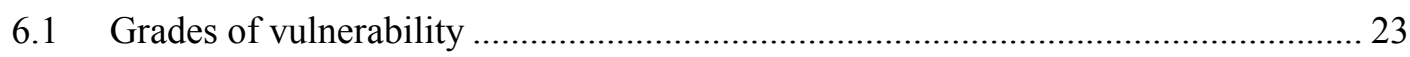

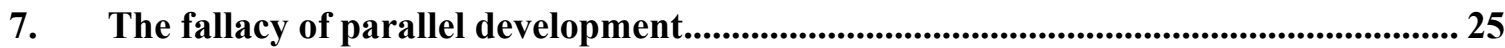

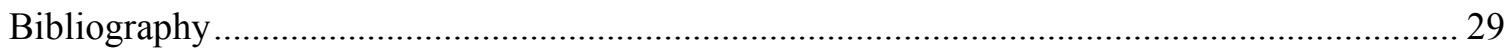





\section{Foreword}

In February 2002, the ILO established an independent World Commission on the Social Dimension of Globalization, co-chaired by President Tarja Halonen of Finland and President Benjamin Mkapa of Tanzania and comprising 26 eminent commissioners from a wide range of walks of life and different parts of the world, each serving in their individual capacity. Its broad goals were: to identify policies for globalization that reduce poverty, foster growth and development in open economies, and widen opportunities for decent work; to explore ways to make globalization inclusive, so that the process can be seen to be fair for all, both between and within countries; to promote a more focused international dialogue on the social dimension of globalization; to build consensus among key actors and stakeholders on appropriate policy responses; and to assist the international community forge greater policy coherence in order to advance both economic and social goals in the global economy.

The report of the World Commission, A fair globalization: Creating opportunities for all, was released on 24 February 2004. It is available on the Commission's website www.ilo.org/public/english/wcsdg/index.htm.

A secretariat was established by the ILO to support the Commission. Among other tasks, it compiled information and commissioned papers on different aspects of the social dimension of globalization. The aim was to provide the Commission with documentation and data on a wide range of options and opinions concerning subjects within its mandate, without committing the Commission or individual Commissioners to any particular position on the issues or policies concerned.

Material from this background work is being made available as working papers, as national and regional reports on meetings and dialogues, and in other forms. Responsibility for the content of these papers and publications rests fully with their authors and their publication does not constitute an endorsement by the World Commission or the ILO of the opinions expressed in them.

\section{Gerry Rodgers \\ Director \\ Policy Integration Department}





\title{
Preface
}

The Technical Secretariat to support the World Commission on the Social Dimension of Globalization first prepared a synthesis of ILO activities on the Social Dimension of Globalization (published as Working Paper No. 1 in this series). Documentation on the work and outcomes of other major commissions, an ideas bank, a database and knowledge networks of experts and social actors were subsequently developed. These networks have dealt with several topics, including: inclusion at the national level for the benefits of globalization to reach more people; local markets and policies; cross-border networks of production to promote decent work, growth and development; international migration as part of the Global Policy Agenda; international governance (including trade and finance); the relationship between culture and globalization; and values and goals in globalization. Gender and employment aspects were addressed throughout this work. The Reports on the Secretariat's Knowledge Network Meetings are available on the Commission's web site or as a special publication from the ILO (ISBN92-2-115711-1).

During the course of these activities, a number of substantive background papers were prepared, which are now made available for wider circulation in the Policy Integration Department's Working Paper series (Nos. 16 to 38), as well as on the Commission's website.

This paper was prepared by Professor Jan Breman of the University of Amsterdam. An earlier version was presented a Knowledge Network Meeting on Exclusion and Inclusion, organized by Kappadath Kannan.

Professor Breman's major interrogation is to what extent globalization is instrumental in overcoming or, alternately, aggravating situations of exclusion? He argues that it is necessary to understand both phenomena in a historical perspective. Exclusion is not of recent origin and cannot only be related to the acceleration in the process of globalization during the last quarter of a century. At the same time, the structure of inequality at the transnational level can only be understood by analyzing the historical trajectory of globalization. Juxtaposing exclusion in opposition to inclusion is detrimental, as focusing on the contrasts helps to understand that the essence is on what lies in between. Prof. Breman looks at the exclusion-inclusion as a continuum, a sliding scale that is subject to changes over time. Questions to be raised are not only exclusion from what and by whom but also since when. Furthermore as important as the perception on exclusion by the excluded, is the perception of exclusion by the included. What are the overt and covert scripts for keeping the excluded part of mankind hidden from becoming visible? Prof. Breman argues that the huge disparities that have been created in today's world cannot be undone without connecting the mechanisms of inclusion to those of exclusion.

\author{
Rolph van der Hoeven \\ Manager, Technical Secretariat \\ World Commission on the Social Dimension of Globalization
}

May 2004 



\section{Social exclusion in the context of globalization}

\section{The notion of exclusion}

The point of departure of this paper is the concept of exclusion, defined as the lack of access to full participation in mainstream society in economic, political, social and cultural terms. Exclusion therefore conveys a sense of denial or loss. The emphasis here is on the relationship between globalization and exclusion: to what extent is globalization instrumental in overcoming or, alternatively, aggravating situations of exclusion? In order to reach meaningful answers to this question, it is necessary to understand both phenomena in a historical perspective. Exclusion is certainly not of recent origin and cannot only be related to the acceleration of the process of globalization over the last quarter of a century. At the same time, the structure of inequality at the transnational level can only be understood by analysing the historical trajectory of globalization.

The condition of exclusion under which people work and live is often operationalized in terms of poverty and inequality. The first dimension refers to lack of assets. Given the absence of means of production, such as land or other forms of capital through which they can acquire income, large segments of the economically active population have to sell their labour to make a living. Poverty becomes particularly acute if: (a) the price of labour is close to or even below the level of reproduction; and (b) unemployment or underemployment is rampant because the supply of labour is structurally much higher than the demand. It often happens that these two factors are interdependent. Exclusion from means of production can lead to exclusion from means of consumption. In those cases, marginality and vulnerability take the form of a pauperized existence.

There are various dimensions to exclusion which do not necessarily overlap. In an economic sense, exclusion refers to the inability to be engaged in gainful employment which yields enough income to satisfy basic requirements. In political terms, exclusion implies a lack of access to sources of power and the inability to participate meaningfully in decision-making processes from the household level upwards. In a social sense, exclusion is equal to denigration, the loss of respectability and dignity in one's own eyes, as well as those of others. Discrepancies between these three dimensions provide room for interventions that might help to bring about inclusion. Suffrage, the one-person-one-vote principle, which became universalized after decolonization in South and South-East Asian societies, increased the political leverage of social classes which in previous generations had remained without voice. To that extent, the introduction of democracy increased the room for manoeuvre of underprivileged people, for instance agricultural labourers in India, stuck at the bottom of the rural economy and society. Experience has shown, however, that a democratic framework is not a sufficient condition for inclusion.

When the various dimensions of exclusion reinforce each other, a pattern of accumulated exclusion arises which is difficult to tackle. Just like the category of the super- or ultra-poor, which has been distinguished in recent literature, it might make sense to identify an underclass of the super- or ultra-excluded. The characteristic of such situations 
is that the various dimensions of vulnerability conflate in a state of segregation, or in other words, a kind of separation from mainstream society that also has a spatial connotation.

Poverty is not necessarily identical to exclusion. People may suffer from deprivation, but if they are not in a position to relate their own circumstances to conditions in which other people live, there is no reason for them to feel excluded. Globalization as a process has certainly helped to extend social horizons and increase aspirations. The new means of communication that have emerged make it easier for people to relate the (inferior) quality of their own life to the (superior) standards enjoyed by others, nearby or far away. Relative deprivation is thus of enormous significance in the definition of exclusion. In the same way, inequality is not a sufficient condition for being trapped in a situation of exclusion. Of course, social systems in which hierarchy is the organizing principle are characterized by a skewed distribution of property, power and prestige. But can people positioned at the bottom of such societies automatically be characterized as excluded? In the earlier literature on caste order in South Asia, the conventional opinion was to define such categories in terms of exclusion: the outcasts, all those living beyond the pale, etc. In sociological terms, however, these categories were very much included, since their presence, as well as the economic services they performed, were required for the higher castes to retain their purity. The meaning of exclusion is to be denied value, to have no constructive role to play in economic or non-economic terms, to be in excess to demand. Social systems based on the norm of equality, on the other hand, do not easily tolerate exclusion. If, for some unforeseen reason, people have stopped being included, the prevalent reaction is to facilitate their return to the fold of the included. In the world at large, and this also has to do with the process of globalization, there seems to be a trend from exclusion towards inclusion, if not in practice, then at least as a social ideal that deserves universal promotion. Exclusion, in the sense of being denied the right to have access to inclusion, may have lost whatever legitimacy it once had.

The juxtaposition of exclusion and inclusion is detrimental to our understanding of both. As in all variations on the concept of dualism, focusing on the contrasts help us to understand that in real life the essence is what lies in between. It would help to look at the exclusion-inclusion divide not as a fixed polarity, but as a continuum, a sliding scale that is subject to changes over time. What also needs to be added here is that awareness of exclusion, or for that matter of inclusion, is dynamic, not static. The questions that arise are not only exclusion from what and by whom, but also since when. Finally, as important as the perception of exclusion by those who are excluded, is the perception of exclusion by those who are included. What are the overt and covert scripts for keeping the excluded portion of humankind from becoming visible?

\section{Globalization and the promise of inclusion}

\subsection{A critical reappraisal}

Wallerstein's seminal work on the emergence of the world system addresses many biases in the interpretation of globalization as a recent phenomenon. For all his criticism, however, this sociologist seems to agree that the development path followed in the third world is essentially a repetition of the transformation process that took place in the Atlantic 
societies during the $19^{\text {th }}$ and the first half of the $20^{\text {th }}$ century. His analysis suggests a transition over the past few decades from agrarian-rural economies to industrial-urban economies. His scepticism mainly concerns the sustainability of the capitalist mode of production at the global level.

His point of departure is the liberation of growing quantities of labour from their captivity in agriculture and their subsequent influx into other economic sectors. With reference to this ongoing trend, Wallerstein speaks of deruralization, which over the past half century in particular has dramatically changed the earlier composition of the global economy. A much greater part of humankind, also outside the first and already highly developed part of the world, has been pushed out from the primary sector of production (Wallerstein, 2000: 261-2). The shift that has come about should not be understood, in my opinion, as basically indicating a repetition of the same process of urban-industrial restructuring which occurred in an earlier epoch in the North Atlantic basin. The exodus from the village economy in the third world does not mean that the swelling numbers of migrants are succeeding in settling down in urban locations. Although, in terms of sheer population size, the big cities have grown more rapidly than ever before, large contingents remain on the march between town and country, as well as between different economic sectors. Such patterns of labour circulation are irrespective of distance, sometimes linking place of origin and destination within one country, or stretching in other instances across continental boundaries. The incessant flow and perpetual rotation are related to employment regimes marked by either own-account work or waged labour, which in the latter case is more often based on casual than on regular contracts. The need for highly flexibilized labour market behaviour coincides with payment for tasks that require little or no skills and schooling. Such are, in sum, the conditions characteristic of a wide range of activities in the informal sector of the economy.

The optimistic statement made by Wallerstein is that the fact of becoming accustomed to this non-agrarian work, regardless of the variable demand for it that results in bouts of unemployment, in the end leads to a higher wage level. For the labourers engaged in this mode of existence, the experience thus acquired provides a take-off point for their subsequent transfer to the formal sector of the economy:

Even where there are large numbers of persons who are technically unemployed and deriving their income, such as it is, from the informal economy, the real alternatives available to workers located in the barrios and favelas of the world system are such that they are in a position to demand reasonable wage levels in order to enter the formal wage economy. (Wallerstein, 2000: 262)

Is his conclusion also justified for the workforce that has become mobile in the towns and country areas of the region in India on which my fieldwork has increasingly been concentrated over the years?

My negative answer has been extensively documented in Footloose labour: Working in India's informal economy (Breman, 1996). Although the income of informal sector workers outside agriculture indeed tends to be somewhat higher than the wages earned by agricultural labourers, a clear majority of the households concerned still have to survive on a per capita income of less than one US dollar per capita per day. This means that the people dependent on informalized employment are in most cases firmly stuck below the poverty line. According to a somewhat more lenient definition of deprivation, which allows not only for bare subsistence, but also for the cost, for example, of housing, medical 
care, education and a modicum of leisure, this level is fixed at a per capita income of at least two dollars per capita per day, not incidentally but regularly. Such existence in "comfort" is quite exceptional outside the realm of the formal sector.

The "discovery" of the informal sector in the urban economy at the beginning of the 1970s went together with the assumption that this zone functioned as a waiting room in which the army of migrants originating from the hinterland could adjust themselves to their new habitat before making their way up to the formal sector, where they would find higher qualified, better paid, more secure and protected jobs. On the basis of my recurrent empirical and local investigations in both India and Indonesia, I conclude that cases of such upwardly mobile trajectories are difficult to find. A series of policy reports in the 1970s and 1980s, commissioned mainly by the ILO, drew attention to what was called the informal sector problem, suggesting measures and regulations to upgrade the working and living conditions of the working poor in third world countries. The same type of analyses and the remedial schemes that accompany them are still being written. This benign strategy, however, has been gradually replaced by the opinion that labour markets in poor countries are in need of more and not less flexibilization. This is at the origin of the suggestion that what is called the unfair and unjust privileging of labour in the formal sector of the economy should be abolished. The protection of a small but powerful vanguard of the workforce should stop and, for the sake of stimulating employment growth, governments are being urged to facilitate the free interplay of market forces. According to the same line of thinking, there is no room for introducing State-initiated schemes of social provision.

These were the recommendations made by the World Bank in a major policy document. I have discussed the substance and recommendations of the World Development Report 1995 in a critical review (Breman, 1995c). A similar argument maintaining that the informal sector is the solution rather than the problem holds that what looks like poverty, defined as lack of property, is on closer inspection a misrepresentation of the capital formation that does in practice take place on an impressive scale in the informal sector of the economy. I strongly disagree with this appraisal, which is partly exaggerated and partly misleading (Breman, 2001b).

I now return to the analysis of Wallerstein, based on the assumption that world capitalism is in an acute and even terminal state of crisis. The ongoing expansion of this mode of production is, according to this sociologist, frustrated by an economic reversal caused by a substantial fall in profit margins. The resulting pressure implies a squeeze on the accumulation of capital, which has always been the organizing principle of capitalism. The investments needed to broaden and deepen markets are drying up. The first of the three factors responsible for the economic turn-around has already been mentioned: rising wages all over the world, which make it impossible for capital to "run away" to still "underdeveloped" regions where the cost of labour is much lower. Capitalist entrepreneurs can no longer adhere to their tested strategy of the continuous relocation of production, but have to confront directly the demands from informal sector workers for more reasonable incomes. The catchment zones of reserve labour in the globalized hinterland, which until now had seemed so inexhaustible, have at last been incorporated into the market economy and, after passing through a phase of being socially uprooted and in political disarray, have finally managed to strengthen their bargaining position vis-à-vis capital and to exert upward pressure on wage levels. From the point of view of labour interests, this is a fairly optimistic assessment which I find it difficult to tally with the sustained poverty of the lower strata in rural and urban India. To an even lesser degree have I seen these people entering the formal waged economy, as suggested by Wallerstein (2000: 261-2). 
Do the profit levels of capital show a declining trend because of the two other factors that he discusses? These relate, on the one hand, to the rising inability of private companies not to include waste removal and cleaning up the environment in their price of operation and, on the other, to the increase in taxation needed for public expenditure. To start with, the first source of pressure, the emergence of the ecological movement, would imply that firms themselves nowadays have to bear the cost of the purification of land, water and air. In the areas of my research in South and South-East Asia, such a decisive swing to private accountability is extremely difficult to discern. The strategy of free enterprise to externalize the costs of pollution seems as yet to be going on unabated. The reluctance of the average State in the third world to take strong action against environmental degradation signals, in my opinion, the raw and untamed nature of capitalism in the global periphery. In those large parts of the world, consumer organizations and other non-governmental agencies have been able to build up much less space to exercise public pressure than in the prosperous core zones of capitalism on which Wallerstein seems to rest his case.

Another source of pressure lies in the steady intensification of taxation. Capital is subject to the demand for public security and is, moreover, no longer in a position to go on blatantly denying popular claims for better education, health care and lifetime insurance. In Wallerstein's judgement, the urge to make these concessions stems from the need to legitimize State action for the as yet underprivileged segments of the population and the concomitant realization among the more well-to-do that such gestures are unavoidable for the sake of further political stability (Wallerstein, 2000: 263). Again, in the course of my empirical research in West India over the past four decades, I have not come across the fear, either among politicians or the bourgeoisie, that the lower social strata pose a serious threat to law and order. Living up to their reputation, gained in an altogether different setting, as les classes dangereuses, the denigration of the labouring poor, which is the dominant attitude in mainstream society, is not tempered by the idea that there is a hidden repository of countervailing power down below waiting to be mobilized against intolerable exploitation and exclusion.

Nor is there any sign of growing support for a more rigorous system of public taxation, or of a shift in the balance of power leading to a more equitable distribution of wealth. The intensification of tax collection by the State does not mean that the better-off are now under closer surveillance insofar as their space to produce and consume is concerned. Indeed, their ability to maximize their private interests has increased. For the masses on the vast subcontinent of South Asia, the opposite could be argued, as the States in question are both unable and unwilling to appropriate a reasonable portion of the value added to capital in the process of production, or even to exercise adequate control over the ways in which capital is spent. Consequently, no social safety nets are introduced which would help to minimize the vulnerability of poor people, and expenditure on public housing, education and health care are much lower than what is minimally required to substantially improve the living standards of informal sector workers.

My conclusion is that the squeeze of capital in the global economy, operationalized by Wallerstein in sharply falling profit rates, has not been taking place in the setting of my sociological investigations over the past 40 years in India. Nor have I found evidence of stagnation in the accumulation of capital. In my view, it would be easier to argue the contrasting thesis, namely the acceleration of capital formation that remains outside the reach of national or transnational governance. Capital has become significantly more volatile between countries and continents, but the ways in which it is moved have not been accompanied by growing control or even transparency. To give one example, there is a 
serious dearth of information on the scale of private financial transfers to many regions in Asia and, conversely, from these to other parts of the world.

The freeing of capital from official regulation is paralleled by a concentration of the surplus, resulting in a progressive tilting of the balance between the haves and the havenots. I would reject the suggestion that my findings have no other validity than for the sites of my fieldwork in Indonesia and India. Indeed, Wallerstein is very much aware that the trend towards polarization has not really halted.

The record of "post-revolutionary" regimes is that they have not been able to reduce worldwide or even internal polarization to any significant degree, nor have they been able to institute serious internal political equality. They have, no doubt, accomplished many reforms, but they promised far more than reforms. And because the world system has remained a capitalist world economy, the regimes outside the core zone have been structurally unable to "catch up" with the wealthy countries (Wallerstein, 2000: 265).

In view of this unequivocal statement, his prediction of a terminal crisis is all the more surprising. Without rejecting the term as such, I would like to give it a meaning that is different from the one that he has put forward. In my perception, the true crisis of world capitalism seems to be the stubborn and pernicious unwillingness to enable a very substantial part of humankind to qualify, both as producers and consumers, for full and fair participation in the regime of capitalist activity. The formalization of labour, in the sense of higher wages, job protection and social insurance, all of which are essential ingredients for a more dignified lifestyle, remains absent. The inevitable result is that the much needed improvement in bargaining power for the labouring poor, which is a precondition for structural rather than conjunctural market expansion, has not materialized.

Mine is an uncomfortable observation which, moreover, does not square easily with the notion that capitalism, more than any other mode of production, is based on the logic of rationality. Are prosperity and democracy for a minority of the world's population in the long term really compatible with the exclusion from these "goods" of a larger part of humankind, which is condemned to live in dire poverty and subordination? In a comprehensive socio-historical analysis, de Swaan has elaborated on the reasons why and the lines along which the national elites in the North-Atlantic basin ultimately decided to admit the labouring poor to mainstream society. At the end of his treatise, the warning comes that the processes of collectivization and civilization which shaped this societal transformation, for various of reasons, but to a large extent also because of the reduced role played by government, may not be repeated on the basis of a similar process at a global scale (de Swaan, 1988: 257).

Quite rightly, Wallerstein has pointed out that people everywhere in the world are taking back from States the role of providing for their own security (2000: 265). My comment is that this trend not to surrender the right to exercise violence may have more to do with aggressive than defensive purposes. In other words, such an inclination could find its inspiration, not in the fear of the unruly behaviour of the poor, but rather in the determination of the elite to resort eventually to untamed brutality in order to consolidate the individual or collective gains made, and even to widen the gap further by not giving to, but taking from the poor. After all, a major trend in the process of globalization is not the alleviation of misery at the bottom end, but progressive enrichment at the top end. 
I disagree with Wallerstein's assessment of a terminal crisis of the world capitalist system. It may indeed be concluded that a crisis is occurring, but the one I discern has not so much to do with falling rates of business profitability, but with the hesitancy of capitalism to deepen markets by increasing the purchasing power of the segments of humankind living in poverty and, in so doing, helping to put an end to their state of exclusion in terms of both production and consumption.

\section{Colonialism as failed development}

From the late $18^{\text {th }}$ until the mid- $20^{\text {th }}$ century, colonialism held a large part of the people in the conquered territories captive in an agrarian-rural mode of production, which remained largely non-capitalist in nature. In more general terms, it could be argued that the global economy as it emerged in the colonial era became structured in terms of severe and increasing inequality. While, in the industrializing and urbanizing West, the hierarchical shape of society lost legitimacy with the waning of the traditional agrarian-rural order, colonialism was the expression of new patterns of inequality at the transnational level, founded on principles of discrimination and racism. The Indian sociologist André Beteille drew attention to the paradox that Western societies were acquiring a new and comprehensive commitment to equality at precisely the juncture in their history when they were also developing in their fullest form the theory and practice of imperialism (Beteille, 1983).

Due to population growth and as a result of colonial policies, a huge mass of land-poor and landless rural workers became congested at the bottom of Asian economies. In the countries of South and South-East Asia, which are the focus of my paper, the landless segments varied from little less than one-fifth to not much more than one-third of the total rural population. Did late colonial policy cause a greater concentration at the foot of the agrarian hierarchy? It is clear that the gradually increasing population density, which became noticeable towards the end of the $19^{\text {th }}$ century and continued during the first half of the $20^{\text {th }}$ century, was of direct influence on the diminishing size of peasant enterprises. It is more difficult to establish whether there was a mass dropping down the agrarian ladder with numerous landowners being degraded, first to tenants and then to landless labourers. During the last century-and-a-half of colonial rule, the variety of sources of employment in the rural economy probably increased very little or even decreased. The latter is said to have occurred in particular in the regions of South Asia where, according to the de-industrialization thesis (the loss of artisanal production organized as home industry), pressure on employment in the agricultural sector increased further. At any event, a reverse trend showed little if any progress. In other words, there was little sign of any advance by industrial capitalism, which had absorbed the surplus proletariat made redundant in the European rural economy. In so far as new industries were established in the colonial metropoles of Asia, rural labour was admitted only on a partial and conditional basis: that is to say, non-working family members had to remain in the village and the labourers themselves were only tolerated in the urban milieu for the duration of their working life. This also applied to the army of landless people who were recruited as coolies for the mines and on plantations in the Asian hinterlands, who were even shipped overseas. Once the contract period had expired, most of them were sent back home or to a destination that passed as such (Breman, 1990). 
The compression at the foot of the agrarian economy cannot have escaped the notice of the colonial authorities. In general, however, they made little effort to redistribute land ownership in order to free peasant production from its perpetual stagnation. An exception to this non-interventionist policy was the introduction, not of a ceiling, but of a floor in access to agrarian property in a region of Java just before the 1920s. Under that reform, land was taken away from marginal land-owners and added to acreage in the hands of their better equipped co-villagers. The stated objective of this experiment was to strengthen the position of the established peasantry. Transition from the marginal to the landless class, so ran official opinion, would enable those who had thus been totally liberated from the means of production to become more flexible on the labour market. Since their tiny plot of land had in any case been inadequate for their subsistence, the measure was said to have been taken for their own good (Breman, 1983: 39-71). In this respect, the opinion of the colonial authorities appeared to run parallel to the suggestion made by Kautsky, among others, that marginal subsistence farmers were actually worse off than free wage labourers. This apparently plausible assumption is not confirmed by my own research based on fieldwork in the rural areas of West India and Java. On the contrary, my findings show that the owners of even a small plot of land have a major advantage over landless households when migrating away from the village and agriculture to find additional employment and income elsewhere.

A survey of conditions in late colonial Asia suggests that it was the combination of economic and demographic change, in particular, that led to progressive land impoverishment. To put it in another way, land ownership at the village level continued to be concentrated largely among a fairly small upper class and a growing proportion of the agrarian population was denied access to holdings other than as tenants or share-croppers. The landless class increased further. It is difficult to come by adequate and reliable statistics to support this quantitative shift in the class structure of the agrarian population. In practice, moreover, it is problematic to distinguish between the class of small landowners and that of agricultural workers. With regard to the latter, Daniel Thorner commented in his well-known analysis of the agrarian structure in India in the mid- $20^{\text {th }}$ century that families in this class may indeed have tenancy rights to the soil, or even property rights, but the holdings are so tiny that the income from cultivating them or renting them out comes to less than their earnings from field work (Thorner, 1976). His observation shows clearly that, to understand the process of (pseudo-)proletarianization in rural Asia, it is imperative not to suggest a sharp divide between the land-poor and the landless, but to see them as extensions of one another. Indeed, in the densely populated regions of agricultural production at the end of colonial rule, they together comprised between half and two-thirds of the rural workforce. Speculations, with all their uncertainty, about the quantitative shift in agrarian stratification under colonial rule must not be allowed to divert attention from the qualitative change that occurred in the social relations of production. In other words, at the end of colonial rule, life as an agricultural worker had become moulded along new lines. That change, and the increasingly capitalist nature of the rural economy in the post-colonial era, had significant repercussions.

\section{Changes to landless existence in the transition to a capitalist regime}

The rural development policies adopted following independence in the mid- $20^{\text {th }}$ century were characterized by a growing trend towards capitalism in agriculture. The much discussed Green Revolution, which gained momentum towards the end of the 1960s, and 
which amounted to the systematic introduction of a modernization package consisting of high-yielding seed varieties, fertilizers and pesticides, credit, new technology, agricultural extension services and better water management, is illustrative of that approach. In contrast to East Asia immediately after World War II, the transformation was not preceded by a drastic redistribution of agrarian resources. Where large landed estates still existed, they were abolished and tenancy relationships were reformed, with the objective of promoting the capitalist stature of a well-established class of owner-cultivators in India, usually members of locally dominant castes. This class, in particular, was charged with increasing production and productivity, as described by a long series of commentators (to mention just a few: Wertheim 1964; Myrdal, 1968; Byres, 1991). Hardly surprisingly, these analyses also point out that the shift in the rural balance of power, which accompanied the development strategy, caused a further deterioration in the already existing vulnerability of share-croppers and agricultural labourers. Myrdal, who saw no other solution to the agrarian impasse, which in his view characterized the Asian drama, advocated a restrained form of rural capitalism. The idea he propagated was:

To give a small plot of land - and with it a dignity and a fresh outlook on life as well as a minor independent source of income - to members of the landless lower strata. Even in the most densely populated countries of the region it would be possible to give the landless at least small plots on acreages that are now uncultivated waste. In some cases land is available for the landless in the vicinity of existing holdings. The existing pattern of cultivated holdings need not be seriously disturbed - in some places it would not need to be disturbed at all. (Myrdal, 1968: II, 1382)

As we now know, little if anything of this modest recommendation has been put into practice. Resources held in common, in so far as these still existed, were rapidly privatized and usually came into the hands of the land-owning elite. In Indonesia, when pressure increased for the new Agrarian Law to be implemented, which was finally adopted in 1960 as a consequence of the political climate of populism in earlier years, the military coup of 1965 put an end to efforts initiated from below to introduce some structural improvement in the position of marginal and landless rural workers, who included the majority of people living in the rural areas of Java (Breman, 1983).

My conclusion is that the capitalist-directed agricultural development policy executed in the post-colonial era has further exacerbated the vulnerability of life at the bottom end of the rural economy. Although the initial sombre reports of the massive expulsion of labour as a result of rationalized and mechanized cultivation methods proved untrue, the expansion of agricultural employment as a net effect of the Green Revolution has not kept pace with the growth of the Asian rural population.

The World Labour Report, published annually by the ILO, shows that self-employment in agriculture is gradually but steadily is making way to wage labour. It would be premature to explain this trend purely as a sign of progressive proletarianization. The replacement of own-account or family labour by hired workers is also due to the emergence of a different life style, causing even middle-sized landowners to prefer to exercise supervision over agricultural work for which outside help is hired. This trend has been a contributing factor to the creation of a rural labour market in the capitalist sense.

The continuing and abject poverty of the great majority of the landless is due to the fact that the supply of labour far exceeds the demand for it. The scenario devised by national policy-makers following independence anticipated the outflow of the surplus proletariat 
towards the urban economy, there to be absorbed into the army of industrial workers. In the former colonial countries of Asia, however, the expansion of large-scale industry has been far slower and, above all, far less labour-intensive than had been planned. Opportunities to escape to the cities are therefore limited, as noted below, while emigration overseas is an equally unrealistic option. People are quite ready to leave their home country, but for the Asian rural surplus there is no New World in which they can settle, as had been the case for the proletarianized mass from Europe a century earlier. Potential emigrants nowadays carry the label of "economic refugees", a term whose strongly negative connotation signals that this ballast in the home economy is not welcome anywhere else in the world. My concluding observations are, firstly, that Asia's rural proletariat emerged from the colonial era as a class of far greater size than in rural Europe, when agriculture still formed the most important source of employment; and secondly, that the sluggish course followed by the industrialization process since the mid- $20^{\text {th }}$ century, in combination with a population growth that has only recently started to decline, has drastically intensified the pressure on life at the bottom end of the rural economy.

It would be incorrect, however, to deduce from the developments outlined above that the nature of landless existence actually signifies a continuation of the labour regime that began to take shape towards the end of colonial rule. Capitalist dynamics subsequently became of dominant significance in the countryside, causing drastic changes in the social relations of production. The transformation derives from three interconnected processes. The first is the diversification of the rural economy. Agriculture has lost much of its significance in the employment pattern in rural areas due to the growing demand for labour in other sectors, such as agro-industry, infrastructure works (roads, canals, houses and other construction activities), trade, transport and all branches of the service sector. Such diversification has naturally not occurred everywhere to the same degree, but the trend in that direction is unmistakable. Sometimes this is employment of the last resort, in an effort to seek redress for the growing under-utilization of labour in agriculture. Greater than the desperate flight away from agriculture, however, is the stimulating effect of the real growth in rural production on other branches of the economy. In the villages of West India where I did my fieldwork, these dynamics have had the result that the majority of the landless can no longer even be classified as agricultural labourers. In these localities, as well as in the State of Gujarat at large, working in the fields is no longer the predominant source of employment and income for the landless. Work at the bottom of the rural economy is characterized by occupational multiplicity. From being an agrarian proletariat, this class has re-moulded itself into a more general rural proletariat.

Economic diversification has been accompanied by the large-scale mobilization of labour. Work away from agriculture usually also signifies work outside the village. Although the drift towards towns and cities has become far greater than in the past, the majority of migrants have little chance of settling there. They accumulate in the informal sector, which is the greatest reservoir of employment in the urban economy. The formal sector has shown hardly any expansion and absorbs little, if any, of the unskilled labour which continues to move in from the rural hinterland. The informal sector is not a transit zone towards a better and settled urban life, but functions as a temporary abode for labour, for which demand fluctuates strongly and which, when no longer needed, is pushed back to its place of origin. It is not departure and arrival that define the migratory chain, in a way that underlines the division between two separate economic circuits, but a continual to and fro of transients which seems to characterize not the rupture, but the linkage between rural and urban labour markets. There is no lack of willingness on the part of this circulatory workforce to engage unconditionally in an industrial way of life, as E.P. Thompson seems to suggest, at least for the initial phase (1991). It is much more a question of sheer impotence, caused by lack of economic and physical space, which prevents the army of 
newcomers from establishing themselves as permanent urbanites, working their way up to become full-time rather than incidental and floating industrial hands.

Labour not only circulates for shorter or longer periods between villages and towns. It also does so, and often in far greater numbers, within the rural milieu in search of work either in or outside agriculture. I have devoted a number of publications to this phenomenon of intra-rural labour mobilization, stressing the connection between long-distance seasonal migration on a truly massive scale and the breakthrough towards a more pronounced capitalist mode of production (Breman, 1985 and 1995a).

Diversification of the rural economy and strongly increased labour mobility are in turn related to a third change in the essence of landless existence which has far-reaching consequences, namely, the casualization of employment. The agricultural economy shows a tendency for permanent farmhands to be replaced by daily-wage labourers, or more generally, employment for an indefinite period has been replaced by short-term labour contracts based on the hire-and-fire principle. This modality also facilitates the replacement of local workers by migrants, with the advantage for employers that workers coming from elsewhere are usually cheaper and more docile, submitting more readily to treatment as a commodity. Moreover, they can be engaged or dismissed according to momentary fluctuations in supply and demand. In contrast with earlier practices, labour is paid principally or even exclusively in cash, and payment in kind in all types of goods, not only for the labourer but also shared by household members, has come to an end. Another important factor is that, rather than paying their workers per day or per year, based on time rates, employers now much prefer to pay for piecework or to contract out the task that needs to be done. Does this mean that production relations have been cleansed of precapitalist elements? To some extent, but not completely. After all, the prerogative of labour to hire itself out at any moment and for the highest possible price is subject to many restrictions. For example, acceptance of a cash advance frequently entails a contract, which immobilizes labour power, while employers also defer wage payment as a tool for ensuring that the required labour, until the moment of dismissal, continues to be supplied. Nevertheless, the lack of freedom caused by such bonding mechanisms differs essentially from servitude, which characterized the coercive regime to which agricultural labour was subjected in the past. "Neo-bondage" is the term that I recommend for the practices used by present-day employers to assure themselves of sufficient cheap labour power.

Having dealt with the historical features of the state of exclusion in which large segments of the rural population came to live and work under colonial rule in South and South-East Asia, two case studies are presented in the final part of this paper which examine how, in a context of globalization, increasing vulnerability can result in a situation in which people are excluded from the employment and income necessary for a life of minimal stability and dignity. Both are local profiles based on anthropological research carried out between 1997 and 2002 and both illustrate that exclusion can be a process in which people are sliding down from a better position that they occupied previously in the economy and society at large. The first report discusses what has happened to rural labour in West Java as, in the aftermath of the Asian financial crisis, their level of employment and income has fallen. The second profile is of urban labour in the city of Ahmedabad. The closure of more than 50 corporate textile mills led to the dismissal of about 100,000 workers who used to be employed in formal conditions. Following the loss of their jobs, they had to find a new living in the informal sector of the economy as self-employed or casual wage labourers. These two profiles, one rural and one urban, are intended to show where, how and why poverty turns into immiserization and takes the form of exclusion. 


\section{Dynamics of exclusion in rural Java}

The crisis which hit the economies of South-East Asia in 1997-98, and Indonesia more than any other country, gave rise to instantaneous and fierce debate. Early on, an alarming increase in impoverishment and unemployment was predicted. The Minister of Manpower then in office went on record as saying that 22 per cent of Indonesia's total workforce would be unemployed by the end of 1998. Backed by official statistics, produced by the Central Statistics Agency (Badan Pusat Statistik, BPS) on the basis of calculations that had never before been disputed, the ILO Regional Office for Asia and the Pacific estimated that the combination of wage stagnation and high inflation might cause 37 per cent of the population to fall below the poverty line by mid-1998, with a further spurt to 48 per cent before the end of that year. In comparison with the all-time low of 10.1 per cent reported for the period before the start of the monetary crisis (krismon, in local parlance) in mid1997, this implied a three to fourfold jump in the incidence of poverty. This was an acceleration that threatened to undo much that had been achieved in raising the standard of living of all and sundry since the mid-1970s. The ILO further argued that the lack of improvement in household incomes and the likelihood of more price rises might even result in two-thirds of the population dropping below the poverty line in 1999. Other international agencies produced more conservative appraisals or forecasts, vehemently rejecting the ILO's doom scenario. In February 1998, the World Bank conceded that absolute poverty might eventually rise to 17 per cent. A year later, a study commissioned by the World Bank reported that the poverty rate had gone up, but only marginally. Subsequent reports suggested that the lower income classes in particular had actually been quite successful in coping with the crisis. The received wisdom was that krismon had had a sharper negative impact on the urban than the rural economy; secondly, it had hit the better off harder than the poor; thirdly, it had reduced waged work in the formal sector of the economy, while employment in the informal sector had expanded. My opinion differs on almost all these scores. For a start, official statistics on economic growth and equity prior to mid-1997 underestimated the magnitude and intensity of the poverty that still existed throughout the country. I would agree with the assessment that a quarter of the population of Indonesia were unable to meet basic needs even before the crisis. Secondly, krismon has caused not only much more misery and loss of employment, but has further widened the divide between the poor, whose numbers swelled rapidly, and the non-poor. Thirdly, the coping mechanisms with which people who have sunk below the poverty level can deal with life's vicissitudes have been exaggerated out of all proportion. Fourthly, notwithstanding some signs of improvement in terms of employment and poverty levels, the crisis is by no means over.

The impression that deprivation under Suharto's New Order regime had become a residual problem found in rather remote pockets of the archipelago, which essentially persisted because these backward areas happened to be beyond the reach of government programmes, was in line with the late colonial myth which suggested that poverty was closely bound up with so-called "minus areas". In contrast to such geo-ecological exceptionalism, I would posit that poverty remained widespread in Suharto's Indonesia, including rural Java. Without a shadow of doubt, the land-poor and landless have managed to dignify their lifestyle and these gains have been reflected in a better quality of housing and the possession of consumer durables. However, the existence of working class households has always remained precarious. The dynamic ratio between productive and non-productive members has made all the difference between living slightly above or below the poverty line. A category of supra-poor could be identified even before krismon began to have its impact. These were the people who had no labour power or were unable to use it fully: the old, the physically or mentally disabled, and widowed or divorced female heads of households responsible for young children. The New Order regime kept a 
great deal of misery carefully hidden behind its propaganda statistics. The incidence of poverty was also understated in the reports of the World Bank and other international agencies.

Major segments of the working classes living close to or in a state of poverty shared only marginally in the benefits of economic growth. The gap that already existed between the elite and the subaltern classes in East Cirebon and North Subang, the two villages of my anthropological fieldwork, has widened further. Contrary to the cherished policy view of rural society in Java as a communal-oriented social order based on patronage and reciprocity between strong and weak, my perception of the processes at work is that emphasis should be placed on polarization and exclusion.

Similar stark contrasts in levels of welfare can, however, be found in rural areas. More noticeable than the reduction of deprivation in the land-poor and landless milieu is the newly gained wealth of the rural elite. This affluence is expressed in the conspicuous lifestyle of a fairly small cluster of notable households, among whom most of village capital assets, both agrarian and non-agrarian, are concentrated. Little light has been shed on the size and identity of the orang kaya baru, a privileged social formation owing the elevation of its members to their role as local agents of the New Order regime, which has consistently opted for a "betting on the strong" development policy. The old colonial myth of "village elders" who acted as representatives of the people with no voice of their own, the masih bodoh, became a lever to create a basis of legitimacy for the exploitation and suppression of subaltern classes in rural areas. Progressive landlessness in the recent past has not merely been a consequence of the ever increasing demographic pressure on agrarian resources, but also of the fact that many households were excluded from cultivating land. The Basic Agrarian Law introduced in 1960 was never implemented. In fact, this effort to ensure a more equal distribution of land by imposing a ceiling on ownership became a bone of contention, which ended in the military takeover of 1965 . It is against this background of a progressive divide between rural rich and rural poor that it is necessary to understand the impact on village Java of the economic crisis which occurred a few years before the end of the last century.

In both villages covered by the fieldwork, the search for livelihood opportunities outside the locality became inevitable over the last quarter of the $20^{\text {th }}$ century. The solution was not found in departure to settle down in other rural areas or in urban destinations. The structural, rather than seasonal, redundancy in the rural economy led to large-scale labour nomadism. This is a pattern of migration that has required young males, in particular, to leave home for variable periods, unspecified in advance, but lasting for several weeks or months. They usually go to a wide range of worksites in or close to urban growth poles. Greater Jakarta and its satellite townships, Jabotabek for short, act as magnets for a massive army of circulatory workers from far and wide in the hinterland of Java. Only a few men and women from both villages have managed to gain access to the formal sector of employment in the urban economy. This is true even of the simplest form of factory work, which may not offer much in the way of protection against the vicissitudes of fate, but at least provides relatively fixed employment with regular working hours and a reasonably steady income.

Most of the migrant labourers from the two villages are unskilled and therefore have little chance of finding regular, reasonably well-paid work. Because they are only employed as cheap and casual labourers, they cannot bring their families to settle permanently in the city. The costs of even the most minimal accommodation and subsistence would simply take up nearly all of their earnings. A state of flux is not therefore a first stage in the 
transition from rural-agrarian to urban-industrial employment, but is more structurally inherent to the conditions under which they continue to live. They are destined to shuttle back and forth interminably, leaving their families in the village. These circular migrants are concentrated in a number of occupational niches. The majority of the men who migrate work as unskilled labourers in the building industry, while others make a meagre living as petty traders and street vendors. Of late, it has become quite common for young women to sign up with recruitment agencies for two-year contracts to work as maids in Saudi Arabia or Malaysia.

Most members in the new generation have turned their backs on agriculture, not only because of its declining importance in the village economy, but also because of a clear preference for an urban-industrial way of life. The prospects of attaining this cherished lifestyle more fully in the near future have largely been frustrated by krismon. Young people from the better off households prepared themselves for the leap forward into the formal economy by obtaining a secondary education and vocational training. Even in earlier more prosperous times, only a few were successful in finding regular and well-paid work in the somewhat elevated echelons of the economy outside the village. Now that the chance of acquiring such work has as good as disappeared, these youngsters seem even more hesitant to join the labour process. So far, parents have shown remarkable restraint, especially where boys are concerned, in accepting this unwillingness on the part of their children to earn a living. The reluctance is in effect a protest by these educated young people against having to perform work for which they consider themselves to be overqualified on the basis of their actually quite modest level of formal schooling. Their contemporaries from the land-poor and landless households that constitute the large majority of the village population cannot allow themselves such luxury. Economic distress forces them to seek paid employment from an early age. Any aspirations they themselves or their parents may have had for the continuation of their education after primary school often have to be abandoned in the face of shrinking household budgets. Consequently, the new generation will not have the opportunity to raise the status of their working life above that of their parents. It is almost a foregone conclusion that they will end up joining the lowest echelons of the informal sector in the rural areas and in the city, performing low-paid and irregular work for a constantly changing series of short-term employers. The prospects of any improvement in the lot of these migrant workers give rise to greater pessimism than optimism, even now that the worst of the recession is over.

There can be no denying that the large segment of circular migrants from both villages who constitute the floating mass of working people at the bottom of the urban economy have been hit heavily by krismon. At the end of 1997, practically all building activity in Jabotabek came to a halt and the kaki lima, the street vendors operating at their own cost and risk, not only lost their customers, but the sharp increase in the price of their raw materials reduced their profit margins. Having become redundant in the informal sector, many were forced to leave. This led to an exodus of the army of labour nomads that had flocked to the cities in the heyday of the Asian miracle, but who had failed to establish themselves permanently in the urban environment. Many of these sojourners instantly dismissed from their casual jobs have been unable to reintegrate fully or even partially into sectors of employment at home. They have responded to their structural redundancy in the village economy by continuing to undertake sorties to the city areas with which they had grown familiar to search for work, with varying degrees of success. Other segments of the working population in the rural hinterland that continued to depend on agrarian and nonagrarian means of subsistence have also suffered, particularly households with few or no means of production of their own. According to my calculations, loss of work and welfare resulted in a contraction of by least a quarter of the gross village product of East Cirebon and by at least one-sixth in North Subang between mid-1997 and 1999. There have been 
some indications of a slight economic recovery from mid-2000 onwards, but this good news seems to be based more on the success of efforts to control inflation than an increase in employment or a rise in real wages. For the time being, there is not much factual evidence of recovery in the substantially diminished standards of living.

There is little thorough empirical or comparative inter-sectoral research to support the conclusion that workers in the formal economy have suffered more from the crisis than those in the informal economy. It is founded on the assumption that elasticity is one of the most striking features of informal economic activity and that the men and women who are forced to eke out a living in this sector will therefore continue to do so during hard times. From this viewpoint, the informal sector expands and contracts like the tide. The reassuring message given out is that the enormous reserve army of labour itself knows best what it should do and where it should go, in terms of both location and sector, in response to a temporary surplus in some or all areas of economic activity. This theory does not, however, hold up in practice. After being sacked on the spot, most circular migrants from East Cirebon had little other choice than to retreat from their employment niches in the metropolitan economy. The same was true for labour nomads from North Subang. Back in the village, their plight can be described as a state of limbo, characterized by a mixture of concealed and open unemployment.

I also contest the oft-voiced claim that krismon has had the greatest impact on the prosperity of the non-poor, and that the position of those without property has not worsened to any significant degree. Once again, there are insufficient reliable and comparative figures to defend or dispute this biased assertion. On the basis of my fieldwork, I conclude that, as a consequence firstly of loss of employment and secondly of the rising prices of basic necessities, poverty did worsen after the outbreak of the crisis, expanding to embrace two-thirds of the inhabitants of both villages by the start of 1999. I estimate that the households with no or very little property that make up this large majority receive only one-fifth of all the income generated. Of particular concern is the advanced degree of exclusion in which the underclass of the ultra-poor, around a quarter of all the inhabitants, find themselves.

The expulsion for the time being of many migrant labourers from the lower echelons of the urban economy following the outbreak of the crisis expressed the failure on the part of the State to provide basic support to this industrial reserve army. With political unrest gathering momentum, policy-makers and politicians were afraid that this redundant mass was about to fulfil its historic destiny as la classe dangereuse. Its expulsion from the urban environment was justified by the argument that, once back in their villages, the migrants would be able to benefit from the traditional mechanisms of social solidarity that had tenaciously survived in the agrarian-rural milieu. During my fieldwork, I found no evidence to support this brand of wishful thinking, which is so popular among politicians and policy-makers. There is no reason to assume that the situation that I encountered in North Subang and East Cirebon, namely advanced monetization of the local economy and the hegemony of contractual relations, is an exception from a general pattern in which the organic principles of what is obstinately referred to as the traditional Javanese culture can still be identified.

I found no evidence that the wealthy upper class households were prepared to spend even a minor part of their surplus to mitigate the misery of their less fortunate fellow villagers. Nor are there any collective arrangements designed to counteract the (increasingly) unequal distribution of wealth. Contractual relations have gradually replaced the former patron-client transactions, in which the wealthy would pledge assistance and protection in 
exchange for the labour and loyalty of the poor. Under the New Order, the elite no longer needed the dependence inherent in the system of patronage to bolster their superiority. The orang kaya baru themselves, however, increasingly became "clients" of those in authority at the district and sub-district levels. In exchange for their support in preserving a social order based on social inequality and political exclusion, they were rewarded by their patrons in the form of preferential drawing rights on the resources of the State.

Would it be possible to detect a culture of shared poverty among the people coping for survival at the congested base of rural society, in an effort to distribute the available work and income as equally as possible, through collective action and mutual solidarity? In neither of the two research localities did I find institutionalized arrangements for households to tie in their fate with others in similar circumstances. As we have seen, during the New Order era, there was no social and political space in which an awareness of common interest could develop among the land-poor and landless classes. The sustained strategy of fragmentation is most probably one of the main reasons why the outbursts of protest that accompanied the deepening crisis did not develop into open and violent class warfare.

In my view, another reason why this did not occur was the increasing opportunity for escape to the urban growth poles. The rapid expansion of employment niches, at shorter or longer distances from home, helped to lower the pressure building up in the rural economy. Large masses of migrant labourers flocked to these growth poles from the hinterland of Java without making a definite break with their milieu of origin. As a result, the bond with the village has remained intact, but it has been weakened. The constant mobility of these circulatory workers, most of whom belong to the subordinated classes, has made them less susceptible to the economic and social power of village elites. This is expressed in a recalcitrance that is a source of irritation to both rural employers and officials. Having become street-wise in the urban economy, the labour nomads enjoy a reputation for being demanding and less malleable than their colleagues who remained stuck in the villages. In mobilizing opposition from below in support of the process of political reform, greater account will have to be taken of the "floating mass" of the people and in a much more literal sense than when the term was coined by those in power under the Suharto regime.

The very many households that play a marginal role in the economic process have little more to fall back on during times of crisis than their own resilience. They of course ask for and receive help from those around them, particularly close kin and immediate neighbours. But given the fact that this assistance comes largely from other poor households, such transfers are limited in scale, regularity and substance. To alleviate the economic distress of those most severely affected, the government could not ultimately avoid introducing what it had consistently tried to neglect, namely a social safety net. This scheme, intended as a temporary solution only, produced little in the way of concrete results. Even the emergency food relief and public works projects, aimed at the poorest of the poor, largely benefited persons outside the ill-defined target groups. The local authorities in North Subang and East Cirebon defended their decision to distribute the emergency provisions to all the villagers by saying that everyone had equal rights to government support. It is my conclusion that this argument was also a logical consequence of the political and bureaucratic myth of the village as a community.

The crisis in Indonesia has stopped being a purely monetary-economic recession and has escalated into the far-reaching disruption of society as a whole. The political instability and the threat to national unity may jeopardize all chances of economic recovery for many years to come. Reforms will only have the desired effect if, at the same time, the people 
are given more say in all matters relating to the quality of their lives. Proposals to shift the focus of political and administrative activity from the national to the regional level must be assessed in this light. These plans are at an advanced stage and a start has already been made in their implementation Without guarantees that the very weak bargaining position of the rural poor will be strengthened, the devolution of political and executive power will result only in legitimizing the informal supremacy of the district and village elites. It is the old principle of "betting on the strong" that has always been at the forefront of Indonesia's development model.

The colonial theory of dualism saw an irreconcilable opposition between two economic systems in rural Java, caused by the penetration of the capitalist forces of production and their clash with a static pre-capitalist society. The main criticism of this dichotomy of stagnation versus dynamism was that it had its origins in foreign domination. Later versions of the same dualistic model, firstly of the city versus rural areas, and then the formal and informal sectors in the urban economy, proved to be just as much a product of their age, enjoying popularity in analyses of the development process in the second half of the $20^{\text {th }}$ century. The current debate on inclusion and exclusion within the context of the globalization of the political economy can be seen as a new variant of the old theme of dualism. The scale of enlargement in terms of production, consumption and distribution has a strongly differential impact on the social classes that become, actively or passively, involved in the global transformations. Since the fall of Suharto, Indonesia has taken the first hesitant steps towards the transition to a civil society based on a democratic order. The progress made on this route will depend largely on whether the far-reaching social exclusion of the subaltern classes takes a turn for the better at the start of a new century. ${ }^{1}$

\section{The process of informalization in Ahmedabad}

The majority of the workers, dismissed from their permanent jobs when more than 50 corporate textile mills closed their gates during the last quarter of the $20^{\text {th }}$ century, ended up in the informal sector of the city's economy. These "new poor" have come to join the already enormous army of workers who have never known a different kind of life. How many people actually suffered a genuine deterioration in their quality of life? The various publications come up with different figures for the number of mill workers who had secure jobs and lost them. My own estimate is that this happened to approximately 85,000 workers who were sacked from the early 1980s onwards. Already, in the decade before the mill closures, the management of these enterprises had reduced the size of the workforce in permanent employment. Casual hands who never qualified for full protection under the labour legislation were not generally hired on a more permanent basis to replace labourers who reached the age of retirement. Some tasks in the production process were also contracted out to jobbers who had to bring their own work gangs, which remained unregistered in the factory records. Of an estimated total of 85,000 workers with regular contracts who were dismissed during the last two decades of the $20^{\text {th }}$ century, somewhat more than 10 per cent may have left the city after being made redundant. Wherever they went, usually back to their place of origin, they only rarely succeeded in gaining access to similar jobs in the formal sector of the economy. Their future was as dark as for the large majority who decided to stay on in Ahmedabad. Another 10 per cent, most of them

\footnotetext{
${ }^{1}$ The full survey has been published as a monograph (Breman and Wiradi, 2002).
} 
belonging to the technical or administrative staff in the mills, were able to find jobs of more or less equal income and skill. Apart from this small segment, which somehow managed to consolidate their formal sector status, all the others, according to my calculations no fewer than 75,000 workers, were eased out into the informal sector, a transfer that implied a dramatic downturn in their fortunes.

If the composition of the household is taken as a basis for determining the impact of the mass redundancies in Ahmedabad, it may be said that, at a conservative estimate, at least 300,000 people, the workers themselves and the members of their households, were directly affected by the dismissal of their main breadwinners from the secure jobs they held in the textile mills. And in addition to these main victims, petty trade, services and transport in the mill localities suffered from the drastic loss of income of the mill households, which constituted a major part of their client base. With the total population of the urban conurbation of Ahmedabad rising from 2.5 million in 1981 to 3.3 million in 1991, the mill closures directly affected no fewer than one-sixth of the city's inhabitants, an undeniably significant proportion. And even that was not the end of the story. As a result of the influx of households expelled from the formal sector, the already fragile existence of workers in the informal sector came under greater pressure than it had already experienced. It is clear that competition for work has led to much tension and conflict, both in residential areas and in relation to work.

For the former mill workers, the initial refusal to accept that the mills had closed for good was replaced by the realization that there was no other option than to look for work elsewhere. The search for new employment was driven by the need to provide for their families, and this period of transition was marked by great insecurity. There was no time and little financial breathing space to recover from the loss of their jobs at the cotton mills. Many could not keep their heads above water without borrowing money from relatives or moneylenders, or asking for credit from shopkeepers. They did this in the belief that, if the mill did not reopen, at least they could look forward to the payment of their savings and the other sums owed to them by their former employers, including their redundancy pay. Those among them who did finally receive their money, considerably less than what they were entitled to, had to use it to pay off the loans and other debts they had run up to survive the period of unemployment.

Slightly fewer than one-third of the ex-mill workers considered themselves unemployable after their dismissal. Half of them gave their age (over 50) as the main reason for not going back to work, while one-fifth put it down to failing health. The rest said that they were willing to work but were unable to find a job. It would be a mistake to take this difference in motivation for their actual behaviour too literally. Age and ill health may be valid arguments for stopping working, but few people who find themselves suddenly unemployed at the bottom of the economy can afford this luxury. It is only possible if other members of the household compensate for the loss in income. In nearly all cases, this proved to have been the case and was the reason why those who claimed to be still seeking work in vain could continue to do so. Unemployment is therefore a flexible concept, determined by what is considered suitable work at any given moment. The final choice, and whether this in turn is eventually revised in the last resort, depends on the balance between the availability of work, conditioned by such factors as the nature of the work and how heavy it is, its regularity, pay and the other terms of employment, and the extent to which the obligation to acquire income for the household can be delegated to other family members. The starting point in the search for other work is always the same: the desire to find a job that, insofar as possible, offers what the mill provided. The absence or inaccessibility of such employment explains why in most cases it has taken so long for 
former mill workers to find a new occupation. The period of idleness was necessary to allow them to adjust their aspirations to a much lower level. As mentioned above, this adjustment was more difficult for some than for others, while a significant group refused to take a step back at all.

The former mill workers would prefer to find work under a permanent contract, but the security and protection provided by such a status ended when they were made redundant. The closest they have come to that now is an unwritten, and even unspoken contract through which employer and employee agree by implication to continue the relationship until the contract is terminated. This is the basis upon which workers are taken on by factories or workshops as wage labourers for an indefinite period, or as guards by companies that specialize in security for industrial premises, offices or residential quarters. As long as the work they do fulfils the requirements of the employer, they can be sure of a job. But they can derive no rights from this employment. Casual labourers, who are hired on a daily basis or until a job is done, are in an even more vulnerable position. This arrangement is standing practice in the building industry. These people assemble early in the morning at one of the many labour markets, which may be a road junction, a square or a bus station, where they wait for the jobbers and subcontractors to come and recruit the labour they need. Sometimes, a relative, neighbour or friend may have asked them to tag along as an extra hand or told them to report directly to the building site. This meeting of supply and demand is not based on legally valid terms of employment and the covert agreement is very vague and fluid.

More numerous than these regular and casual wage labourers are those who are self-employed, working on their own account. Three of the most common occupations in this respect are rickshaw drivers, street vendors (of cloth and garments, food and drinks, crockery, vegetables) and repairing or recycling waste materials. Others work at home, making garments, paper, toys or plastic articles on a subcontracting basis. Although they are without doubt economically active, they find it difficult to specify their main occupation. This is also because many of them have to be engaged in several trades to earn enough to keep their heads above water. Then there are those who are active only occasionally. They work some days and not others, depending on the demand for their services. They are not overly active in seeking work, but do not refuse it if it is offered to them.

The ex-mill workers are now employed in jobs that typically require a far lower level of capital investment than the work they performed in the mills. If mechanized power is involved at all, it is in the form of simple machines (a rickshaw motor, a sewing machine or other simple equipment, for example for repairing clocks and watches, radios, bicycles or household articles, or craft tools for producing handmade commodities, such as leather goods, furniture, ambar charkha or paintbrushes). Only the weavers in the power loom sheds work on the same machines that they used in the mills, which were sold as scrap. The skill level outside the industrial sector of the economy is much lower, and it is especially in these branches (small-scale trade, transport and services) that a large proportion of the former mill workers have ended up. Many of them have lost the skills that they learned in the mills. On the other hand, their work now demands much greater physical effort. Complaints from construction labourers, pedal rickshaw drivers, cart pullers, head porters and ambulant street vendors about being exhausted at the end of the day must partly be seen in the light of the fact that they now work far less with machines. 
The work in the mills had a daily rhythm of eight hours, leaving enough time to spend with the family, do household chores and engage in activities outside the home. This is now completely impossible. On paper, the power loom workshops are supposed to operate according to a three-shift roster. As everyone knows, however, the working hours are split up into a day shift and a night shift, each lasting ten to 12 hours. The employers will not take anyone on for less. More is, of course, always possible. If someone does not turn up for work, a member of the previous shift can simply work another ten or more hours. Homeworkers can decide for themselves how many hours they work, but the pressure to earn more by starting early in the morning and working until late in the evening is great. Often, all the members of the household play some part in the production, leaving very little leisure time for them to spend together. Others who work in the open air at their own expense can determine the length of their own working day. Street vendors offer their wares long after night has fallen and have to be up and ready to replenish their stocks at the break of day. Lastly, there are the not inconsiderable numbers who have to spend part of the day or night doing a second job to supplement their low income. The former mill workers have to cope not only with much longer, but also much more irregular working hours. Although they used to work three eight-hour shifts, the shift schedule was drawn up in advance and they were paid extra for overtime. Such bonuses are a thing of the past and the regular cycle of their working lives has been replaced by erratic and unpredictable interruptions and long periods of idleness during which they are not paid. The fact that they show up for work is no guarantee that they will actually be employed on any particular day. It is often uncertain whether the working day will begin at all and how it will develop, and the workers are expected to adapt to these major and often unpredictable fluctuations. Free days and leave have become a luxury and are never paid.

More than any other criterion, the enormous drop in income illustrates the degree to which the quality of life of the former mill workers has deteriorated. The weavers who now earn their living in small enterprises do the same work, but for much lower pay. Nor can they always be sure that there will be work for them. Most ex-mill workers who earned a daily wage of between Rs 90 and 100 before the mills closed, for an eight hour day, six days a week, amounting to between Rs 2,000 and 3,000 a month, now earn less than half of that, while a sizeable minority have to make do with less than one-third of what they earned previously. The fall in income is so dramatic that other members of the household are forced to work. The wage brought home by the man of the house was sufficient to allow customs to be observed or imposed, but following the closure of the mills there has no longer been the financial freedom for such sensitivities. Home-working allowed Muslim and some Hindu women to take an active part in earning income for the household without them having to break the social code of public behaviour. Sewing and embroidering clothing, making incense sticks and rolling cigarettes are prime examples of activities in which all household members, particularly women and children, can take part. But in many cases, women and children also are forced to engage in work outside the house. They are employed in garment workshops, but may also have to seek work as domestic servants. Collecting paper and other waste (such as scrap metal or empty plastic bottles), which has a low status and earns very little, is the speciality of dalit women and girls.

In some of the households of former mill workers, the shortage of income has sometimes become so acute that impoverishment has given way to outright pauperization. The household members can no longer afford to buy the basic necessities to survive. But even in the much larger numbers of households where the fall in earnings has been less severe, it is still hard to make ends meet. As a result of the gap between income and expenditure, the proportion of the household's budget that has to be spent on food is much larger than before and many have been forced to cut back on both the quantity and quality of their 
daily food consumption. The tradition of celebrating family events with lavish meals and new clothes has been abandoned and little or no money is left for the purchase of consumer durables. Although the lifestyle of the industrial workers allowed for few comforts, the large majority of ex-mill workers are connected to electricity and water supply, and two-thirds have a toilet in or close to the house. A bicycle and a table or ceiling fan are relatively normal and the majority have a radio and a sewing machine. A little under half still enjoy the luxury of a television set or a pressure cooker, purchased in better times. Many have had to sell such valuable possessions, and even more are no longer able to repair them if they breakdown. About half own the house they live in. The remaining rent their homes for around Rs 100-150 a month. Although many of these tenements are located in what have now become slum districts, this does nothing to impair their value for those who live in them. The quality of the dwellings has, however, suffered across the board, as the residents find themselves unable to afford even the most basic repairs, for example to roofs or walls. And rent that was formerly well within their means has now become an almost unbearable burden.

A greater threat to the well-being of the former mill workers and their families than the deterioration in their food intake is the loss of their right to free or cheap medical care. In the past, they were members of the Employees State Insurance Scheme (ESIS), set up by the Government in 1948 for employees of public and private-sector enterprises. Employees and employers fund ESIS from contributions, while the Government also provides a sizeable subsidy. Under the statutes of the scheme, the workers' families are eligible for medical services, which are provided cost free. ESIS has its own hospitals and neighbourhood clinics, with its own doctors who see patients and prescribe medicines. When workers retired or were unable to go on working due to disability, insurance coverage continued for them and their wives, but those who lost their jobs for other reasons were automatically excluded from the scheme. To their great anguish and resentment, this is what happened to the mill workers when they were dismissed. The benefit that the workers derived from their membership of ESIS was much greater than the contribution they paid into the fund and represented not less than 10-15 per cent of their salary. Now that they are no longer insured, they try to rely on self-help and only call in low-grade doctors and quacks if they have no choice. These practitioners, who are often not properly trained, charge much more for a consultation or an injection than the insurance scheme. And there is neither the money nor the professional expertise for the treatment of the stress and other mental problems that arose during and after the redundancy period.

The future of the new generation of children is in jeopardy because their schooling is cut short. Parents can no longer afford to invest in improving the life chances of their offspring. Primary school attendance is not affected much, but the impact on more advanced education has been much greater. Apart from the fact that the cost of intermediate and vocational schooling far exceeds the household budget, the labour power of youngsters is a much needed source of income that has to be tapped at an early age. As a consequence, the level of knowledge of the new generation when they enter the labour market at a very young age is often lower than that of the mill workers when they started their working lives many years ago.

Former mill workers also worry a great deal about their children's life partners and the cost of marriages. Looking for suitable candidates is time-consuming and assumes that the parents have the opportunity to deliberate carefully on their choice. Financial considerations play a decisive role in the negotiations, which aim to secure the best candidate at the lowest price. In the absence of a reasonable dowry, gifts of money and 
commodities with which the arrangement is sealed, girls in particular are forced to accept partners who would never have been eligible before. A lower status, not only for the individual but also for the whole family, is the price that has to be paid.

Building up the reserves needed in times of crisis is now completely out of the question. And setbacks occur more often and with greater intensity than before the mill closures. Initially, the workers could use their redundancy benefits, but these varied greatly in size and many received nothing at all. How was this money used? A small minority managed to deposit at least part in a savings account and were resolved not to eat into it until the time came for which it was intended, usually for the purchase of a house, future repairs or the marriage of sons or daughters. A much larger number indicated that they had to use the money to pay for medical care, urgent home repairs or the repayment of debts. By far the largest share was spent on day-to-day expenses since, with the difficult adjustment to a lower level of income, this was the only way that the households could meet their recurrent needs. Clearly this situation, in which expense exceeded income, came to an end when the reserves were exhausted. Redundancy payments were far less than most of the workers were entitled to and, moreover, were paid in instalments over an extended period. This explains why workers could not resist the temptation to spend the money as it came in. Most of them therefore clung to their previous way of life and consumption pattern for much longer than they were able to afford.

The dramatic fall in the standard of living of the former mill workers undermined their self-confidence. After the shock of being expelled from the mill came the discouraging experience of looking for a new job, accompanied as it was by the loss of skill and a much lower wage. We heard how the men were completely at a loss in the early days following their dismissal. They would not talk for days on end and refused to take food. Their loss of vitality was so great that even the lightest of physical activity was seen as too exhausting. Some stayed at home, others left the house early in the morning and came back late at night, refusing to disclose where they had been or what they had been doing. This state of shock easily led to health problems, which had previously received little attention. Such ailments were used as an excuse to avoid helping with the daily household chores. ESIS medical records show an increasing number of patients in the industrial neighbourhoods with heart problems and high blood pressure. The greatest demand was for social care and psychological counselling, but this was not covered by the insurance. Social relationships within the family suffered. Husbands and wives quarrelled, often leading to violence by the man, and sometimes even vice versa. Tensions also increased between parents and children. According to primary and secondary school teachers in the industrial neighbourhoods, children became unruly and "difficult", had problems concentrating and complained about troubles at home.

No visitor to Ahmedabad can fail to observe the sprawling slums on the East bank of the river, which have spread rapidly over the past few decades. A large segment of the city's population is cramped together in these deprived quarters, exposed to environmental degradation and excluded from the most elementary civic amenities. There is a close link between living in a slum and working in the informal sector of the economy. The tall chimneys marking the industrial landscape have disappeared and the factory compounds, which for a century or more were congested worksites with people constantly milling around, are vacated and deprived of their economic significance. Working class neighbourhoods no longer surround the new wastelands, which are filled with the rubble of demolished buildings and now dominate this part of the city. The lack of steady employment and a sharp fall in incomes have transformed these habitats of the former mill workforce into slum localities. 
The alienation of the ex-mill workers from mainstream society finds expression in their reduced access to public services and institutions, including those that are intended for each and every citizen of Ahmedabad. This state of exclusion is accompanied by a loss of control over the conditions that determine the quality of their lives now and in the future. Market discrimination in how they live and work reinforces their acute sense of deprivation and ensures that they do not enjoy equal opportunities to improve their situation. Members of stigmatized groups naturally seek contact with their own kind Muslims, dalits and other social minorities exposed to discriminatory practices, individually and collectively - for mutual support and protection. A life of dependency, however, goes hand-in-hand with restricted choice and downward mobility. Indebtedness forces the former mill workers to sell their own labour power and that of other household members and to settle for a lower wage in exchange for advance payment. Such dependency restricts other options and investment in forms of horizontal solidarity that cut across primordial loyalties. There is an impelling need to retreat into their own communal niche and to stay aloof from other social segments.

The retrenched textile workers are not the only inhabitants of the industrial districts to have suffered from the collapse of the large-scale textile mills. The impact on petty trade, services and transport in the mill areas has been enormous, because demand for the services of a wide variety of shopkeepers, street operators and craftsmen came predominantly from this leading segment of the working population employed in the formal sector of the economy. Many of their customers have become their competitors. The influx of households expelled from the formal sector has put even greater pressure on the already fragile existence of workers in the informal economy. Competition for work has led to much tension and conflict, both in residential areas and at the workplace. The process of levelling down to the bottom has become manifest in the spread of squalor and has helped to create an atmosphere of undiluted depression.

\subsection{Grades of vulnerability}

From early morning until late in the evening, the chalis and side roads are crowded with people. The large majority are males of all ages, lying, sitting or standing in front of their houses or hanging around in small clusters. They take to the streets to kill time because there is not much else for them to do. Women who are not engaged in outside work tend to stay at home, not only because of a code of conduct which does not allow them to move about freely, but also because they are busier than their male partners with all kinds of household chores and in making use of their labour through gainful employment.

Few labourers in the informal sector of the economy succeed in working more than 20 days a month. Street vendors seem to be the most susceptible to seasonal fluctuations, which prevent them from achieving a fixed rhythm of work. On days when it is raining, cold or very hot, there is less demand for their services and they have to face a considerable drop in income. Daily wage labourers are similarly affected. On such days, they go to the various labour markets in the city where workers are hired early in the morning, only to be turned away. It is the same story at the building sites, where they seek work as unskilled hands. It would, however, be incorrect to attribute the unpredictable nature of work in the open air purely to inclement weather. It may also by interrupted by public holidays, or by disturbances of the public order, such as riots or political tensions. Seasonal swings in the city's economy, caused by not so transparent flows of industrial and mercantile capital in the informal sector, have a greater impact on the mass of workers in 
this sector than on their counterparts in the better-regulated formal sector. Not much is known about the nature and effects of these cyclical and erratic trends. They also affect homeworkers, whose means of earning a living are wholly concealed from public view. The fact that they are apparently available for work at all times does not mean that they have work all the time. The delivery of raw materials is irregular, the power supply is unreliable and contractors pass on fluctuations in demand for the end product without the slightest scruple.

The large amount of time not spent in gainful work does not mean that this vast reserve army enjoys the many and erratic hours of non-activity at their disposal. Leisure used to be a familiar notion that grew out of the pattern of regular employment in the mill. When they were not on night shift, the men would congregate in small groups after the evening meal and sing devotional songs or just engage in small talk together on street corners. Going alone or with the whole family to the Sunday market on the riverbank or to visit relatives living in other neighbourhoods were favourite outings during the weekend. These days are gone. Although there is more "idle time" available now, there is neither the money nor the energy to enjoy it as leisure.

Not all workers who have lost their mill jobs have fallen below the poverty line. There are those who do not have to rely solely or predominantly on the sale of their unskilled labour power. These include the owners of petty means of production, such as motorized rickshaws, handcarts or street cabins, or of parcels of land or small buildings in the slum areas, who not only use this property themselves but rent or lease it out. Although the percentage of workers having access to various forms of petty capital should not be exaggerated, their households are certainly better off than those who have no means of production themselves. At the opposite end of the spectrum, there is an extremely vulnerable segment of ex-mill workers who, because of ill fortune or disability, are alienated both from means of production and consumption. The households to which they used to belong have broken up. There are instances of men deserting their wives and children, unwilling to provide for them any longer, but there are also cases of men being thrown out of their houses soon after losing their jobs at the mill. Such people, the ultraexcluded, roam the streets as lost souls, begging and afflicted by acute pauperization. They depend for their irregular and inadequate meals on ramroti, free food distribution centres run by religious charities.

Slum life is not only characterized by signs of want, deprivation and neglect. The closure of the mills has also led to a shrinking of public space in the settlements surrounding them. Places where people used to meet their workmates and others with different social identities are nowadays difficult to find. Certainly, in the past too, the mill hands used to spend most of their time off in or around the home, mainly within the confines of the particular communal circle to which they happened to belong. Life-cycle events or religious festivals were public functions, which were largely celebrated in the open. The neighbourhood schools run by the municipality were a point of contact where children not only demonstrated the skills picked up within the intimacy of family life in dealing with "others", but where they also made friends from the other side of the fence. People living nearby were invited to share in the food and fun, even if they observed other customs themselves. There were clubs, which gave training in wrestling, boxing and other sports to all-comers, irrespective of their caste or communal background. And the spectators at the matches were also mixed. The reading rooms set up by the Textile Labour Association (TLA) throughout the industrial districts were also important meeting places. Classes were held in the mornings and evenings to teach adults and those who had dropped out of school at an early age how to read and write. Later on, many of these centres were taken over by 
the Labour Welfare Board, an official agency set up under the auspices of the municipal government. In recent years, several of these places have closed down for lack of funds. The municipal corporation decided to cut down on social expenditure and the clientele has dwindled. Apart from the inability of the clients, men as well as women, to pay the very modest fee charged for the various courses or for the crèches where toddlers can be left a few hours each day, they have also lost their appetite for spending "free" hours in constructive activities. Their time is eaten up in the search for work, or just in remaining "idle". Venturing out into mainstream society has become an option that many households in the milieu of ex-mill workers can no longer afford.

\section{The fallacy of parallel development}

A paradigm, which has dominated post-colonial development literature in the second half of the $20^{\text {th }}$ century, suggests that inclusion is a historical trend encompassing more and more people in different parts of the world. This particular brand of wishful thinking suggests that the process of transformation, as it has taken place in Western economies, will be repeated at the global level and will in the end give rise to the kind of industrialurban society that initially emerged on both sides of the Atlantic Ocean in the northern hemisphere. No doubt, that historical trajectory was also difficult to predict when it first commenced. Towards the end of the $19^{\text {th }}$ century, there were strong doubts that the underclasses in Western societies would be able to find their place in the new industrial society that was being constructed. The doctrine of social Darwinism was based on the assumption that not all poor people could or, for that matter, should be raised to a life of human dignity. In the struggle for survival, only the fittest in the process of natural selection would be able to qualify for a better future. When compared with the deserving poor, kept in waiting as a reserve army of labour, the non-deserving poor were labelled as a burden to themselves and to society at large. This sizeable segment of the poor were blamed for their own poverty. Having nothing useful to add, their very presence was considered to be a risk to social stability and cohesion.

The subsequent inclusion of these marginalized groups into mainstream society was the outcome of a highly labour-intensive process of industrialization. The low level of technology, although rapidly increasing, allowed for the insertion into the workforce of households pushed out of the agrarian-rural economy. What came to be redefined as the social question, conditioned on the one hand by growing assertiveness from below and, on the other, by acceptance among the higher classes that the cost of exclusion might be higher than inclusion, had its origin in an expanding economy which required the labour power of the masses living in poverty. There is no clear indication that this development scenario, which took place within the framework of the nation State, has been replicated at the transnational level a century later. On the contrary, the enormous gap between nonpoor and poor people is still widening.

The assumption of parallel development explains why, in the post-colonial era, politicians and policy-makers have gone on record as saying that "soon" or in "the foreseeable future" people would no longer have to live in poverty. While they might have conceded that the fight against deprivation would take time and was dependent on all kinds of preconditions, they did not state that bringing increasing numbers and ultimately all people above "the poverty line" was something that could not or even should not be contemplated. A wellknown example of that mode of thinking was the idea of "trickle down", which promised 
hat people with few or no assets were eventually going to benefit from the process of economic growth.

In line with the notion of inclusion as a historical trend, the British sociologist T.H. Marshall specified various dimensions of the process of inclusion and ranked them in sequential order: first, the granting of legal rights which extend the rule of law to all citizens; next, the granting of political rights which proclaim universal suffrage and promote the participation of all in a democratic framework; and finally, the granting of socio-economic rights which find their apex in the welfare state (Marshall, 1975).

There have been episodes in the recent history of developed societies which have seemed to signal that the trend towards inclusion could be abruptly halted or even reversed, resulting in a slide back into exclusion. The world economic recession in the 1930s once again exposed many people in the industrialized countries to a situation of vulnerability, which they found difficult to accept, precisely because of their improved well-being in the preceding decades. In 1933, a book was published, entitled Die Arbeitslosen von Marienthal, consisting of an empirical study of the effects of long-term unemployment (Jahoda et al., 1933). The book became one of the classic works of social scientific literature on the significance of the loss of paid employment for working class households in an industrial society. The setting of the study was a small community on the outskirts of Vienna, which had one large textile mill and not much else by way of economic activity. After cutbacks in production and working hours in the late 1920s, against the background of the economic crisis which affected the whole of industrial Europe, the mill closed in 1930. This signified the disappearance of what was essentially the only source of employment in this rural township. With the complete workforce made redundant, no less than three-quarters of the local population, 367 of the 478 households, found themselves in a situation of acute and stark poverty. In summing up their findings, the authors spoke of die müde Gesellschaft ("the tired community"). This subtitle of their study expressed the feelings of powerlessness and hopelessness that overwhelmed these people. Only a small proportion of the population managed to stay in paid work, in the service sector outside the village, and a number of older people received a pension. The study describes the response of the affected households in subsequent phases: how they proceeded from initial resolve to resignation, going on to despair and finally apathy. The social psychological approach illustrates how these people lost their sense of time and how their daily routine, which is so important for a meaningful life, was eroded. Outside the household, there was a noticeable increase in isolation, a declining involvement in the world outside, institutionally and organizationally, together with symptoms of envy and suspicion instead of mutual help. The tenor is clear: a process of marginalization and a shrinking of the psychological space, leading to alienation. The portrait demonstrates how tempting it is to hold the poor themselves accountable and responsible for the state of exclusion in which they are made to live.

How did the dismissed Austrian workers survive in those years of crisis? Certainly not through being able to find paid employment, but by partially retreating into selfsufficiency. They grew vegetables or bred rabbits on a small piece of land rented to them by the mill or the local council. Much more important than these modest contributions towards imposed autarky, however, was the unemployment benefit that they received from the State every fortnight. The economic cycle of the households affected by the mill 
closure revolved around this paltry payout. The benefits were funded from contributions by employers, workers and the local authority, and the total accumulated in the years prior to the closure of the mill meant that there were enough funds to last for 20 or 30 weeks. After that, the former mill workers were eligible for the lower benefits provided by a government "dole" system. Sporadically, such as on religious holidays, the municipality or charity organizations would provide them with food packages. In the early $1930 \mathrm{~s}$, the welfare state in Europe was still under construction. It would not be expanded and completed until well after the end of World War II, but the foundations had already been laid in the early years of the $20^{\text {th }}$ century. When the economic crisis struck in the early 1930 s, governments in the industrialized part of the world responded to the sudden onset of unemployment and impoverishment with relief programmes. These took the form of both financial support and job creation through the commissioning of public works. It is precisely this type of public scheme which, in the free market driven policies towards the end of the $20^{\text {th }}$ century, has been lacking or soft-pedalled in the global fight against poverty.

The essence of my argument in the pages above has been that past experiences are relevant to defining, analysing and resolving the dynamics of inclusion-exclusion in what is called the developing world. In order to promote incorporation into mainstream society and to forestall a return with a vengeance of the doctrine of social Darwinism in the globalized economy, the deeply skewed balance between capital and labour will have to be redressed. Such a corrective policy needs to be carried out at the transnational, national and local levels and requires: (a) capital redistribution (land reforms in the first place); (b) employment creation and job security; and (c) the provision of social welfare, concretized in terms of health, housing and education.

The huge disparities that have been created in today's world cannot be undone without connecting the mechanisms of inclusion to those of exclusion. As Seabrook, for example, has argued, it seems to be the object of official political discourse to suppress any such connections:

The easiest alibi, as always, is to blame "nature", drought, over-population, the spread of the desert; when it is our own nature that is deeply implicated, above all the nature of our society and its development, which has succeeded in re-creating a lasting sense of impoverishment out of the very riches it has accumulated, and has made us believe that the simple goal of sufficiency for all represents for us, the rich, not emancipation, but a terrifying loss not to be contemplated. (Seabrook, 1985: 175) 


\section{Bibliography}

Beteille, A. 1983. The idea of natural inequality and other essays. New Delhi, Oxford University Press.

Breman, J. 1983. Control of land and labour in colonial Java: A case study of agrarian crisis and reform in the region of Cirebon during the first decades of the twentieth century. Dordrecht, Foris.

- 1985. Of peasants, migrants and paupers: Rural labour circulation and capitalist production in West India. Oxford, Clarendon Press.

- 1990. Labour migration and rural transformation in colonial Asia. Rotterdam, CASP.

- 1995a. Wage hunters and gatherers: Search for work in the rural and urban economy of south Gujarat. New Delhi, Oxford University Press.

- 1995b. "Work and life of the rural proletariat in Java's coastal plain", in Modern Asian Studies, 29(1), 1-44.

- 1995c. "Labour get lost: A late-capitalist manifesto", in Economic and Political Weekly, 30(37), 2294-99.

- 1996. Footloose labour: Working in India's informal economy. Cambridge, Cambridge University Press

- 2000. The impact of the Asian economic crisis on work and welfare in village Java. Dies Natalis lecture, The Hague, Institute of Social Studies. Reproduced in Journal of Agrarian Change, 1(2), 2001, 242-282.

- 2001a. A turn for the worse: The closure of the Ahmedabad textile mills and the retrenchment of the workforce. Wertheim Annual Lecture 12. Centre for Asian Studies, Amsterdam School of Social Science Research, University of Amsterdam.

- 2001b. A question of poverty. Valedictory Address to the Institute of Social Studies, The Hague.

— and Wiradi, G. 2001. Good times and bad times in rural Java. Leiden, KITLV Press.

Byres, T.J. 1991. "The new technology, class formation and class action in the Indian countryside", in Breman, J. and Mundle, S. (eds.), Rural transformation in Asia, New Delhi, Oxford University Press.

Jahoda, M. P., Lazarsfeld and Zeisel, H. 1933. Die Arbeitslosen von Marienthal [The unemployed of Marienthal]. Leipzig.

Marshall, T.H. 1975. Social policy in the twentieth century. London, Hutchinson (4th ed.).

Myrdal, G. 1968. Asian drama: An enquiry into the poverty of nations. (3 Vols). New York, Pantheon.

Seabrook, J. 1985. Landscapes of poverty. London, Blackwell.

Swaan, A. de. 1988. In care of the state: Health care, education and welfare in Europe and the USA in the modern era. Cambridge, Polity. 
Thompson, E.P. 1991. Customs in common: Studies in traditional popular culture. London, Penguin.

Thorner, D. 1976. The agrarian prospect in India ( $2^{\text {nd }}$ ed.). Bombay, Allied Publishers.

Wallerstein, I. 2000. "Globalization or the age of transition: A long-term view of the trajectory of the world system", in International Sociology, 15(2), 249-265.

Wertheim, W.F. 1964. "Betting on the strong", in East-West parallels: Sociological approaches to modern Java. The Hague, Van Hoeve.

World Bank. 1995. World Development Report 1995: Workers in an integrating world. New York, Oxford University Press. 


\section{Policy Integration Department Working Papers prepared for the World Commission on the Social Dimension of Globalization}

No. 16 International finance: Meeting the needs of people in developing countries, José Guilherme Almeida dos Reis

No. 17 The gender dimensions of globalisation of production, Stephanie Barrientos, Naila Kabeer and Naomi Hossain

No. 18 Social exclusion in the context of globalization, Jan Breman

No. 19 Gender and globalization: A macroeconomic perspective, Çağatay Nilüfer and Ertük Korkurt

No. 20 Globalization, social exclusion, and work: With special reference to informal employment and gender, Marilyn Carr and Martha Chen

No. 21 Resources for social development, Antony Clunies Ross

No. 22 Does the new international trade regime leave room for industrialization policies in the middle-income countries?, Alisa DiCaprio and Alice Amsden

No. 23 Social dimension of globalisation in Latin America: Lessons from Bolivia and Chile, Alvaro García Hurtado

No. 24 Globalization: Social impact and policy actions: A partly annotated bibliography, Bernhard Gunter and Rolph van der Hoeven

No. 25 The social dimension of global production systems, Susan Hayter

No. 26 Reforming global economic and social governance:

a critical review of recent programmatic thinking, Jeremy Heimans

No. 27 Corporate social responsibility: An issues paper, Michael Hopkins

No. 28 Upgrading in global value chains, John Humphrey

No. 29 Implications of globalization and economic restructuring for skills development in Sub-Sahara Africa, Richard K. Johanson

No. 30 The outcome and impact of the main international commissions on development issues, Frédéric Lapeyre

No. 31 Globalization and structural adjustment as a development tool, Frédéric Lapeyre

No. 32 Globalization and perceptions of social inequality, Malte Luebker

No. 33 The changing structure of trade linked to global production systems: what are the policy implications?, William Milberg

No. 34 Corporate social responsibility: An overview of principles and practice, Jill Murray

No. 35 Inclusive development strategy in an era of globalization, Ignacy Sachs

No. 36 Social consequences of the globalization of the media and communications sector: Some strategic considerations, Seán Ó. Siochrú

No. 37 Globalization, history and international migration - A view from Latin America, Andrés Solimano

No. 38 Towards a different kind of globalization, or how the anti-globalizers view the world, Gijsbert van Liemt 
